
\title{
R Reserach S Suare \\ Determination of The Intensity and Georeferencing of Urban Heat Islands in Temuco, Chile
}

\author{
Aner Martinez-Soto ( $\square$ aner.martinez@ufrontera.cl ) \\ University of La Frontera \\ Michelle Vera-Fonseca \\ University of La Frontera \\ Pablo Valenzuela-Toledo \\ University of La Frontera \\ Aliwen Melillan-Raguileo \\ University of La Frontera
}

\section{Research Article}

Keywords: Various methodologies, IHU, UHI, Temuco

Posted Date: February 8th, 2021

DOI: https://doi.org/10.21203/rs.3.rs-156219/v1

License: (c) (i) This work is licensed under a Creative Commons Attribution 4.0 International License.

Read Full License 


\section{Abstract}

Various methodologies to estimate the intensity of urban heat islands (UHI) have been proposed. However, there is no consensus on their combined or individual use. This study presents and analyzes the validation of the combined use of methodologies to capture data from UHI'a (mobile transects and fixed stations) and the location of the UHI phenomenon by considering the city of Temuco, Chile as a case study. The database used for the fixed station methodology consists of twenty-three stations belonging to the National Monitoring Network of Chile distributed throughout the city. For the mobile transect methodology the database was generated with three cars that crossed the city simultaneously taking one temperature record per minute. The results show that the two methodologies yield similar results, so it is possible to obtain the intensity of the IHU phenomenon using at least one of them. The results also showed that Temuco has a maximum intensity of the $\mathrm{UHI}$ phenomenon of $13^{\circ} \mathrm{C}$, with this value being one of the highest recorded in UHI studies in the world.

\section{Introduction}

The development of urban centers and their expansion towards the peripheral areas have directly affected variations in the weather patterns of cities ${ }^{1}$. The transformation of natural surfaces that served to dissipate the energy radiating on surfaces and that could store and emit energy has produced a temperature increase in cities ${ }^{2,3}$. This phenomenon is called urban heat islands (UHI), and their intensity is defined as the temperature difference observed between urban zones and rural or adjacent sectors at a given moment ${ }^{4,5,6}$.

Increased power consumption for air conditioning to compensate for the high temperatures in buildings within the UHI generates polluting gases like carbon dioxide and nitrogen oxide, which are considered precursors of the ozone accelerating the formation of $\mathrm{smog}^{7}$. This directly contributes to global warming, forming a vicious circle $^{8}$. According to the Intergovernmental Panel on Climate Change (IPCC), between 1983 and 2012 an increase in global temperature occurred ${ }^{9,10}$ that ranged between $0.6^{\circ} \mathrm{C}$ and $0.8^{\circ} \mathrm{C}$, and it is expected that for the year 2100 the temperature will increase between $1.4^{\circ} \mathrm{C}$ and $5.8^{\circ} \mathrm{C}$ compared to 1990 temperatures $^{11}$. A particular case is the city of Kuwait: since 1972 their temperatures have increased by $0.3^{\circ} \mathrm{C}$ and $0.8^{\circ} \mathrm{C}$ per year, with temperatures over $50^{\circ} \mathrm{C}$ becoming more frequent ${ }^{12}$.

The increase in global temperature has brought with it sustained periods of high temperatures called heat waves. During the presence of heat waves the UHI phenomenon is amplified, altering people's comfort and health ${ }^{6,13}$. In Europe in 2003, around 70,000 people died due to a heat wave $\mathrm{e}^{14}$. In Russia and India in 2010 and 2015 respectively, more than 20,500 people died ${ }^{14}$, victims of heat waves, the consequences of which are augmented in $\mathrm{UHI}^{14}$.

$\mathrm{UHI}$ can be perceived in any season of the year and are visualized in both the day and night ${ }^{15}$. A study in lași, Romania reported that the temperature difference between the city center and adjacent sectors 
varied between 3.0 and $4.0^{\circ} \mathrm{C}$ at night ${ }^{16}$. In Mexico City it was determined that the temperature difference in the day varies between 3.0 and $5.0^{\circ} \mathrm{C}$ in the rainy season ${ }^{17}$. In Akure, Nigeria during the dry season, the temperature difference between the rural and urban sectors was $4.4^{\circ} \mathrm{C}$ at 21:00 $\mathrm{h}^{18}$. In Toledo, Ohio there was a $2.0^{\circ} \mathrm{C}$ difference between the city center and its adjacent sectors throughout the year ${ }^{19}$. In 2002 it was determined that in Phoenix, Arizona, the temperature difference between the urban and rural sectors varied between $0.8^{\circ} \mathrm{C}$ and $5.4^{\circ} \mathrm{C}^{20}$. From this it is deduced that the $\mathrm{UHI}$ phenomenon is present in various cities regardless of their geographic location.

Several methodologies are used to determine the intensity of the $\mathrm{UHI}$, including data capture using mobile transects, fixed stations and satellite analyses ${ }^{21}$.

Data capture using mobile transects has been employed for the design of urban connection networks for more than 40 years $^{22}$. It is prioritized when fixed stations are insufficient to create an accurate representation of the phenomenon ${ }^{22}$. However, its measurement period is limited compared to the other methods. Martínez (2014) used this method to determine the intensity of the heat islands in the city of Alicante and concluded that the maximum intensity of the phenomenon was $4.5^{\circ} \mathrm{C}^{23}$. However, the measurement of the intensity only represents a static moment in the day, which does not visualize UHI behavior throughout the day.

The evaluation of UHI using fixed stations is suitable for measuring temperature near the surface ${ }^{17}$. Giannopoulou (2011) used this method to determine the characteristics of UHI in Athens in summer, concluding that the intensity of the phenomenon in the city reached $5^{\circ} \mathrm{C}^{24}$. However, this methodology can produce distorted results when there is a limited number of stations ${ }^{25}$. Erell and Williamson (2007) also mention that the fixed networks are more expensive and prone to vandalism, which limits their acquisition and conservation in large numbers ${ }^{26}$.

Stewart (2011) indicates that the satellite analyses provide more accurate results, taking measurements for long periods of time ${ }^{27}$. However, Konstantinov (2015) notes that the temperatures obtained via satellite are not always accurate, determining an error of measurement of $1.68^{\circ} \mathrm{C}$ in the city de Apatity 28 . Hardy and Nel (2015) used this method to determine the intensity of the UHI in Johannesburg, concluding that the temperature difference between the rural and urban sectors varied between $2^{\circ} \mathrm{C}$ and $3.5^{\circ} \mathrm{C}^{29}$. However, this methodology does not analyze the air temperature in the city, but rather it is influenced by the heat absorbed by the urban infrastructure and is detected by satellite images.

Although the intensity of the UHI phenomenon has been determined in different cities around the world, no comparison or validation of the results using combined methodologies has been found. This raises the need to evaluate simultaneously the phenomenon of atmospheric UHI in the same city with the different existing methodologies to determine the correlation of the results that these methodologies provide and have the certainty that their individual or combined use is both reliable and viable $30,31,32$. 
Studies into the measurements of the intensity of the UHI phenomenon have been conducted in several countries. However, these studies have been carried out in countries whose boundary conditions, for example the typology of the houses, vegetation or climate are not extremely different. The case studies where the UHI can be substantive and the boundary conditions are extremely different are still pending. In this sense, countries like Chile represent a particular case in terms of UHI since the climate and vegetation of the cities vary according to their geographic location. In Chile studies have been conducted measuring the intensity of the UHI phenomenon by mobile transect and satellite images $a^{1,3,33,30}$. Nevertheless, these studies are concentrated in the central zone, which is not representative due to the country's length and climatic variability.

The aim of this study is to measure and analyze the UHI intensity in Temuco, Chile using the fixed station method contrasted with the mobile transect method. The objectives of this study are the validation of the combined use of methodologies in the data collection and georeferencing of the location of UHI in the city, the thermal imbalance of which affects people's quality of life.

\section{Methods}

\section{Study Area}

The city of Temuco is located at latitude -38.735932 and longitude -72.590409. It has a surface of 464 $\mathrm{km}^{2}$ and is delimited by the Ñielol and Conunhueno hills with heights of $335 \mathrm{~m}$ a.s.l. and $360 \mathrm{~m}$ a.s.l. respectively. The Cautín River is located between the hills and crosses the city northeast to southwest.

According to the United Nations (UN) ${ }^{42}$, the population of Temuco has been growing steadily in recent decades. Between 2002 and 2015 the city's population grew from 227,086 to 275,617 inhabitants ${ }^{43,44}$. This population growth has brought with it the construction of a large number of residential neighborhoods. This in turn entails the replacement of areas with vegetation for elements with the capacity to absorb the heat, resulting in an increase in temperatures in the city ${ }^{45}$.

Temuco is classified according to the Köppen climate classification as Csb (warm-summer Mediterranean climate). It is characterized as having cold winters and dry summers; mean temperatures exceed $10^{\circ} \mathrm{C}$ and its maximum and minimum temperatures range between $23^{\circ} \mathrm{C}$ and $1^{\circ} \mathrm{C}$ respectively ${ }^{46}$. The temperature records from previous years have been taken by the Meteorological Office of Chile using an official station located in a zone bordering the city in the Maquehue sector (Coord.: -38.76778, -72.59417). According to the temperature data recorded at the Maquehue station, $6.65 \%$ of the days between 2000-2019 reached maximum temperatures over $30^{\circ} \mathrm{C}$, reaching $40.2^{\circ} \mathrm{C}$ in 2019 (February 15 $21: 00 \mathrm{~h}$ ). In the previous period between $1980-2000$, only reached $3.2 \%$ of the days had maximum temperatures over $30^{\circ} \mathrm{C}$; thus, the temperatures over $30^{\circ} \mathrm{C}$ have doubled in the last two decades. These increases in temperature even entail the annual average temperatures being higher than those stipulated in the Köppen classification. In Temuco the maximum daily temperatures appear in summer, with 
February being the month with approximately $50 \%$ of the highest temperatures, followed by January with $43.75 \%$ and March with $6.25 \%$.

\section{Procedure to contrast heat island location methodologies}

It has been determined in the existing literature that UHI can be classified in two types: surface urban heat islands (UHI's) and atmospheric urban heat islands (UHI'a) ${ }^{47}$. The former is understood as the thermal difference between artificial and natural surfaces, while the latter is understood as the difference in air temperature between the different zones in the city ${ }^{47}$. The methodologies used to determine the intensity of UHI vary according to their classification. Satellite image analysis is used to determine the intensity of UHI's, whereas the mobile transect or fixed station methods can be used to determine the intensity of UHI'a ${ }^{31}$.

In the present study UHI'a were analyzed, so the data needed to evaluate their intensity were captured using mobile transects and fixed stations. Both methodologies were based on the capture of air temperature, which made it possible to contrast both databases and calculate their Pearson's correlation coefficient, the interpretation of which is presented in Table 1. Additionally, to contrast and compare the two methodologies, the average difference, maximum temperature difference recorded by the two methodologies and the standard deviation between the two data sets were used.

Table 1 Coefficient classification of Pearson's correlation values according to Zühlke ${ }^{48}$.

\begin{tabular}{|lll|}
\hline Correlation & Pearson's correlation coefficient $(r)$ & Interpretation \\
\hline Perfect & $r=1$ & Perfect similarity, identical profiles. \\
\hline Very strong & $0.75 \leq r \leq 1$ & Very similar, significant similarity. \\
\hline Medium & $0.50 \leq r \leq 0.75$ & Moderate similarity \\
Weak & $0.00 \leq r \leq 0.50$ & Little similarity \\
\hline None & 0.00 & No correlation \\
\hline Very weak & $-1 \leq r \leq 0.00$ & Very large differences, opposite curves \\
\hline
\end{tabular}

\section{Mobile transect method}

The method performed with mobile transects consists of roaming data collection through the city along a previously defined route ${ }^{49}$. The temperatures of the cities were recorded each minute by two HOBO Pendant MX2201 sensors and a HOBO Pendant MX2202 sensor. These sensors have a rapid response to thermal variations and their measurement ranges cover from $-20^{\circ} \mathrm{C}$ to $70^{\circ} \mathrm{C}$ with an accuracy of $\pm 0.5^{\circ} \mathrm{C}$. 
Prior to the data collection, the three sensors were calibrated by capturing air temperatures with direct radiation and low shade. This measurement was used to verify that the temperature records captured by the three sensors were similar, with a maximum variation of $\pm 0.15^{\circ} \mathrm{C}$ among them.

The sensors were positioned on the passenger side window of three cars that crossed the city simultaneously at an average speed of $30 \mathrm{~km} / \mathrm{h}$. For each data capture the corresponding coordinates were taken via GPS. The measurements were taken between 20:00 and 20:30 since in this period there is no influence of direct solar radiation and the elements of the city begin to release their heat absorbed during the day. The data are downloaded via Bluetooth on the free platform HOBOmobile, available for Android, IOS and Windows.

To determine the route to take with the mobile transects, the UHI phenomenon was analyzed based on the data recorded by ReNaM in Temuco on November 27, 2017 and January 19, 2018. On these days, the highest annual temperatures were recorded, reaching $28.5^{\circ} \mathrm{C}$ and $31.4^{\circ} \mathrm{C}$ respectively. The high temperatures on these days generated UHI in four zones (Z-1, Z-2, Z-3 and Z-4) in the city (Figure 7). The methodology used to locate the $\mathrm{UHI}$ at this stage is presented in chapter 2.3. It must be mentioned that for the determination of the mobile transect route a previous simulation of the $\mathrm{UHI}$ is necessarily required. This helps to guarantee that the thermal profile generated by the mobile transect more accurately represents the phenomenon.

Figure shows that there are four main zones in the city (in red), where the UHI phenomenon occurs. Zones Z-1 (Coord.:-38.709179,-72.554418) and Z-3 (Coord.:-38.742428,-72.643479) are characterized as having little vegetation in the urbanized sectors compared to the high green surface around it. Thus, the temperature in the sector is affected by direct radiation during the day. Meanwhile, zones Z-2 (Coord: $-38.753900,-72.624335)$ and Z-4 (Coord.:-38.726355,-72.619119) have a lot of traffic congestion during the day, which increases the anthropogenic heat, promoting high temperatures in the sector.

Based on the location of heat islands from previous years, the decision was made to perform three routes simultaneously (Figure 8). The Transect 1 route (red) had a total distance of $10.50 \mathrm{~km}$, crossing the city from north to south by the main avenue (Av. Caupolicán) passing through Z-1 and Z-2. The Transect 2 route (magenta) crossed the zones Z-3 and Z-4 including a total distance of $10.35 \mathrm{~km}$ from the western sector of the city in a northeast direction. The Transect 3 route (green) had a total distance of $10.73 \mathrm{~km}$, initially crossing the city from north to south and then edging along the Cautín river in an east-west direction crossing Z-2. Additionally, it was defined that the Transect 2 route begins where the Transect 3 ends in order determine if there was a temperature reduction rate over the period when the measurements were taken. It was ensured that all the trajectories of the mobile transects were within the isothermal map created based on the fixed stations (chapter 2.3).

\section{Fixed Stations Method}

To conduct this study using the fixed stations method, temperatures measured by the National Monitoring Network (ReNaM in Spanish) were used. The network has 23 intelligent sensors (Netatmo) 
represented in Figure 8 by black dots; these are installed in private homes distributed in various zones in Temuco.

The Netatmo weather stations are comprised of two devices (interior-exterior) of UV-resistant aluminum with a measurement range from $-40^{\circ} \mathrm{C}$ to $65^{\circ} \mathrm{C}$ with an accuracy of $\pm 0.3^{\circ} \mathrm{C}$. The sensors installed on the outside are protected from rain and direct solar radiation to avoid deteriorations and a better accuracy in capturing data. The time interval with which the data are captured is thirty minutes, configured in closed schedules so as not to have variations in the capture time, for example: 8:00-8:30-9:00 etc. The sensors were calibrated and validated by the Ministry of Housing and Urban Development (MINVU) in conjunction with the Chile Foundation.

Prior to the measurement of the intensity of the UHI with both methodologies, the temperature data from the $\mathrm{HOBO}$ and Netatmo sensors were contrasted. It was determined that the average variation between the sensors was $0.48^{\circ} \mathrm{C}$. This implies that the possible temperature variations obtained with both methodologies at the same geographic point would not be heavily influenced by the different devices used for the measurement.

\section{Methodologies for UHI simulation and location in Temuco}

The methodological framework used to produce images of urban zones with UHI and a fluctuation plot that compares the maximum and minimum temperature in the city is based on the classic methodology of data export adapted for the UHI simulation context ${ }^{50}$. This methodology consists of (1) Analysis and data processing, (2) Methodology for data processing, (3) Sampling, dimensionality reduction and use of distance functions.

First, the temperature data set from December 4, 2019 is observed. This day the Maquehue station reached a high temperature $\left(25.4^{\circ} \mathrm{C}\right)$ compared to the temperatures on the other days in December 2019. Second, the preprocessing of this data set consists of: (1) format change, i.e., modification of records with an erroneous numerical format; (2) elimination of dates with no associated data, meaning that only the dates with records in at least one network station were included; and (3) generation of a new data file, i.e., a new file with the data ready to be used in the image generation process. The result of this process is a file in CSV format (comma separated values) that includes the parameters of: Date-Time, Station identifier (Id), Temperature [ $\left.{ }^{\circ} \mathrm{C}\right]$, Latitude and Longitude (Table 2). Finally, the image generation process is described using the previously mentioned data set. In the step, two types of images were generated: (1) Heat islands, and (2) Fluctuation plot.

Table 2 CSV file format with parameters Date-Time, Id, Temperature, Coordinates (Latitude, Longitude) processed from ReNaM data. 


\begin{tabular}{|lllll|}
\hline Date-Time & $\mathrm{Id}$ & $\mathrm{T}\left[{ }^{\circ} \mathrm{C}\right]$ & Latitude & Longitude \\
\hline 2017-01-10 00:00:00 & 245 & 9.0 & -38.721 & -72.600 \\
\hline 2017-01-10 00:00:00 & 246 & 9.4 & -38.707 & -72.665 \\
\hline & $\cdot$ & $\cdot$ & $\cdot$ & $\cdot$ \\
\hline & $\cdot$ & $\cdot$ & $\cdot$ & $\cdot$ \\
\hline 2018-12-11 23:30:00 & 294 & 15.2 & -38.740 & -72.648 \\
\hline
\end{tabular}

The UHI-related images make possible the visualization of the phenomenon at a certain time. For this, isotherms were deployed that link stations records with equal temperatures, using Delaunay's triangulation as the theoretical base ${ }^{51}$, i.e.: (a) All the points must be connected to each other and form the greatest number of possible triangles without their corners overlapping. (b) The triangles are defined by joining the points closest to each other. (c) The formed triangles must be as regular as possible, maximizing smaller angles and minimizing the length of the sides ${ }^{51}$. Each isotherm is drawn with a different color, associating red with high temperatures and blue with low temperatures.

The fluctuation plot corresponds to the daily visualization $(24 \mathrm{~h})$ of the station temperatures that recorded the highest and lowest temperature input during the phenomenon. In turn, the results of the temperature data provided by the official Chilean weather station located in the Maquehue sector are included in this plot (Figure 8), visualizing the behavior of Temuco by making a point outside the city.

The intensity of the phenomenon for every period of time was obtained using the equation: UHI = TUmax - TUoRmin. TUmax corresponds to the maximum urban temperature captured in the city, whereas TUoRmin corresponds to the minimum urban or rural temperature recorded in the city or its adjacent sectors. The intensity of the UHI phenomenon for Temuco was classified according to Table 3.

Table 3 Classification and temperature ranges associated with UHI intensity based on ${ }^{52}$. 


\begin{tabular}{|lll|}
\hline Classification & Intensity & Interpretation \\
\hline Weak & $\begin{array}{l}\mathrm{UHI} \leq \\
2^{\circ} \mathrm{C}\end{array}$ & $\begin{array}{l}\text { There is no major difference between the temperature in the city and } \\
\text { adjacent sectors }\end{array}$ \\
\hline Moderate & $\begin{array}{l}2^{\circ} \mathrm{C}<\mathrm{UHI} \\
\leq 4^{\circ} \mathrm{C}\end{array}$ & $\begin{array}{l}\text { There is a slight difference between the temperature in the city and } \\
\text { adjacent sectors not perceptible by people }\end{array}$ \\
\hline $\begin{array}{ll}\text { Strong } \\
4^{\circ} \mathrm{C}<\mathrm{UHI}\end{array}$ & $\begin{array}{l}\text { The difference in temperature between the city and adjacent sectors is } \\
\text { moderately perceptible by people }\end{array}$ \\
\hline $\begin{array}{l}\text { Very strong } \\
6^{\circ} \mathrm{C}\end{array}$ & $\begin{array}{l}6^{\circ} \mathrm{C}<\mathrm{UHI} \\
\leq 8^{\circ} \mathrm{C}\end{array}$ & $\begin{array}{l}\text { There is a big difference in temperature between the city and adjacent } \\
\text { sectors very perceptible by people }\end{array}$ \\
\hline $\begin{array}{l}\text { Extremely } \\
\text { strong }\end{array}$ & $8^{\circ} \mathrm{C}<\mathrm{UHI}$ & $\begin{array}{l}\text { The difference in temperature between the city and adjacent sectors is } \\
\text { extreme and dangerous for people }\end{array}$ \\
\hline
\end{tabular}

The stations used for the fixed-station measurements record data every thirty minutes, whereas the sensors used in mobile transects record data every minute. Therefore, for the generation of temperature data with the same frequency as the mobile transects (one minute), the temperature data of each fixed station were interpolated for thirty minutes.

\section{Results}

\section{Comparison of fixed station and mobile transect methodologies}

Figures 3,4 and 5 illustrate a comparison of the temperature records obtained using the mobile transect and fixed station methodologies. These records were compared to determine how close the values are that these methodologies provide and to be able to validate their use separately or combined.

Transect 1 covered the route represented in red in Figure 2 of $10.5 \mathrm{~km}$, where temperature data were captured every one minute. The route took thirty minutes, where thirty points were captured along the route. Figure 1 provides the graphical representation of the temperatures recorded by the transect contrasted with the temperatures obtained by isothermal maps given by the fixed station methodology. It is observed that both methodologies yield similar temperature records. From record $\mathrm{N}^{\circ} 1$ to record $\mathrm{N}^{\circ} 12$ there is an increase in temperature, after which there is a decrease until record $\mathrm{N}^{\circ} 15$. The similarity between the records obtained with the two methodologies is confirmed with the correlation coefficient of 0.55 . 
The greatest maximum temperature difference between the two methodologies at the same point reached $1.76^{\circ} \mathrm{C}$, located at the moment at which the city is entered, where the change in temperature is considerable. However, the average temperature difference captured by the two methodologies along the entire route was $0.72^{\circ} \mathrm{C}$, which implies that the classification of the UHI phenomenon is not altered by the points that have the greatest temperature difference. The standard deviation between the two temperature data sets is 0.5 . This value is very close to the accuracy of the sensor, which implies that the dispersion of the data is not significant.

Transect 2 performed the route represented by magenta in Figure 2 which took 26 thirty-six minutes. The circuit covered $10.35 \mathrm{~km}$, where 36 temperature records were captured. It might be considered that unlike Transect 1 the route ran through sectors with high traffic congestion, which acquired a larger amount of temperature data in a shorter distance. In Figure 2(a) it is possible to visualize with the fixed station methodology that there are four zones in the city with high temperatures. These zones are not clearly reflected in the mobile transect methodology. However, it is noted that the intensity of both temperature records decrease until record $\mathrm{N}^{\circ} 29$, when they begin to increase their intensity again. The similarity between the values is confirmed with the correlation coefficient of 0.61 , a value classified as mean correlation.

The greatest maximum temperature difference captured by both methodologies at the same point was $2.91^{\circ} \mathrm{C}$, whereas the average temperature difference captured by both methodologies at the same point was $1.6^{\circ} \mathrm{C}$, a lower value than the ranges for which the $\mathrm{UHI}$ is defined, which does not alter its classification. The standard deviation that yields this temperature data set is 0.65 . This value indicates that despite analyzing the intensity of the phenomenon with the most distant record, its classification would not change.

Transect 3 performed the route represented in green in Figure 2 of $10.73 \mathrm{~km}$, where data were captured for 30 minutes, creating a record of 30 points. Although the distance was greater than the other transects, the sector encompassed has few traffic lights, which makes the traffic steady and flow better. Figure 2(b) shows that the similarity in the two records is greater than Transects 1 and 2 . With both methodologies it is observed that the journey goes between zones in the city that have a lower temperature to zones with a higher temperature. Figure 2(b) shows that both temperature intensities of the zones covered begin to decrease until record $\mathrm{N}^{\circ} 8$, the point where the temperatures in the zones begin to increase. This similarity that the records have in the increase and decrease in their intensity in similar ranges is confirmed by the correlation coefficient of 0.62 . This value is classified as mean correlation.

The greatest maximum temperature difference captured was $2.7^{\circ} \mathrm{C}$, whereas the average temperature difference captured by both methodologies at the same point was $1.2^{\circ} \mathrm{C}$, a lower value than the ranges for which the UHI intensity is defined that does not alter its classification. The standard deviation obtained from this temperature data set is 0.91 , a range in which the data tend to disperse.

\section{Location of heat islands in Temuco}


Figure 3 shows the isothermal map (left) and fluctuation plot (right) generated at the time and in the sector where the city reaches its maximum temperature. The maximum temperature reached in Temuco is visualized on the isothermal map in Zone 3 (Coord.: $-38.740785,-72.645474$ ) at $14: 00 \mathrm{~h}$ with $33.1^{\circ} \mathrm{C}$. The minimum temperature reached in the city at the same time was located in Zone 2 (Coord.: $-38.745916,-72.633190$ ), with $29.7^{\circ} \mathrm{C}$. The intensity of the UHI phenomenon was $3.4^{\circ} \mathrm{C}$, being classified as a moderate UHI. However, when calculating the intensity of the phenomenon on the basis of the temperature of the Maquehue station at $14: 00 \mathrm{~h}\left(20.1^{\circ} \mathrm{C}\right), 13^{\circ} \mathrm{C}$ of difference are obtained between the urban and rural sectors, which classifies the $\mathrm{UHI}$ as extremely strong. The fluctuation plot (Figure 3, right) also shows that the maximum temperature in the city (Stn. 288) increases and decreases in short periods of time. This may be due to the fact that in the zone where the temperature peak is reached, there is abundant vegetation and most of the infrastructures are isolated houses, which allows for rapid air circulation and therefore reduces the temperature in the sector.

In Figure 3 it is observed that in addition to the zone with the maximum temperature (Z-3), there are two sectors that tend to have a higher temperature than the rest of the city (Z-1 and Z-4).

Figure 4 (left) shows the 24-hour temperature fluctuation at station 247 in Zone 4 (Coord.:-38.733095, -72.6031539 ), where a temperature of $30.2^{\circ} \mathrm{C}$ was recorded at $14: 00 \mathrm{~h}$. When calculating the temperature difference in the sector compared to the temperature at the Maquehue station at the same time, a UHI intensity of $10.1^{\circ} \mathrm{C}$ was obtained, a value classified as an extremely strong UHI. However, when calculating the temperature difference that exists between city sectors, an intensity of $0.5^{\circ} \mathrm{C}$ was obtained, classifying it as a weak UHI. Figure 4 (right) represents the temperatures at station 256 in Zone 1 (Coord.:-38.697133,-72.535842), which reached a temperature of $31.8^{\circ} \mathrm{C}$ at $14: 00 \mathrm{~h}$. When determining the intensity of the UHI phenomenon, there was a difference of $11.7^{\circ} \mathrm{C}$, classifying it as an extremely strong UHI. By linking the minimum temperature found in the city to the temperature in the sector at the same time, a temperature difference of $2.1^{\circ} \mathrm{C}$ was obtained, classifying it as moderate UHI. When comparing any point of the city with an external point, intensities over $10^{\circ} \mathrm{C}$ were reached. This would mean that the UHI phenomenon would influence the microclimate in every sector in the city.

\section{Discussion}

The results of the comparison of the temperature records obtained using the mobile transect and fixed station methodologies show similar UHI intensities in Temuco. The correlation coefficients of the three circuits varied between 0.55 and 0.62 , being classified as a moderate correlation. It may be inferred from this that both methodologies can analyze UHI intensity, obtaining similar classifications. This would also imply that both methodologies deliver reliable results used either individually or complementarily.

The time to perform the three routes with the mobile transects was approximately thirty minutes. The transect 2 route began at point $-38.756761,-72.646664$, where a temperature of $20.68^{\circ} \mathrm{C}$ was recorded. On the other hand, the transect 3 route included at the end of its run the temperature record at the same point as the start of transect 2 . The temperature recorded at the same geographical point, but with a 30-minute 
delay for transect 3 , was $20.80^{\circ} \mathrm{C}$. This indicates that the temperature of the city in the time period when the measurements were taken (thirty minutes) using mobile transects had no significant variations. However, it must be considered that, were the run time to be extended, there could be a temperature variation in the city, which would involve making time corrections to the recorded values.

It has been noted that the fixed station methodology is expensive, and the stations are subject to vandalism ${ }^{26}$. Therefore, in terms of installation and maintenance costs, using mobile transects makes more sense. Nevertheless, it must be considered that the mobile transect methodology can classify the $\mathrm{UHI}$ intensity, but only considering thermal profiles. By contrast, the fixed station methodology permits an overall analysis of the UHI phenomenon in the city. Here it is also inferred that for the choice of routes for the mobile transects, it is essential to know beforehand the location of the zones where the UHI are located, which is why the fixed station methodology would be a suitable complement.

The temperature difference of each measurement point in Temuco and the control station located in Maquehue on December 4,2019 at $14: 00 \mathrm{~h}$ ranged between $0.2^{\circ} \mathrm{C}$ and $13^{\circ} \mathrm{C}$. This demonstrates that the temperature in the entire city is higher than that of the neighboring rural sectors. The maximum intensity of the UHI phenomenon in Temuco was $13^{\circ} \mathrm{C}$, which is why it is classified as extremely strong (Table 3 ). This value was recorded when the temperature at the Maquehue control point was $25.4^{\circ} \mathrm{C}$.

Using a linear projection it is expected that in heat wave scenarios (temperatures higher than $30^{\circ} \mathrm{C}$ for more than 3 consecutive days), the temperatures of the zones identified as $\mathrm{UHI}$ in Temuco exceed $43^{\circ} \mathrm{C}$. This temperature would directly affect people's mortality, because as Hajat et al. (2002) have demonstrated (2002), in heat wave periods deaths increase $5.73 \%$ for each degree over $23.3^{\circ} \mathrm{C}^{34}$.

In Figure 5, a temperature comparison appears for two heat wave episodes (1 and 2) that occurred in February 2020 between the Maquehue station (MS1 and MS2) and the zones with the highest temperature in Temuco (Z-1 to Z-4 in Figure 8). Here, it is observed first that the maximum temperature in Temuco occurs between 15:00 and 16:00 h, which represents a behavior that does not follow the common pattern of the UHI phenomenon. The maximum temperature peak in most of the cases studied was reached between 19:00 and 20:00 h. However, in the case of Temuco at that time the temperature in the city dropped, whereas outside the city (Maquehue) the temperature reached its daily maximum.

Additionally, the maximum temperatures recorded in the city had an average increase of $26^{\circ} \mathrm{C}$ in a short period of time (between 10 and $15 \mathrm{~h}$ ). The same speed of temperature change appeared from $16 \mathrm{~h}$ where it reached on average $5.3^{\circ} \mathrm{C}$ per hour. This is higher than the maximum acceptable temperature change rate $\left(3^{\circ} \mathrm{C} / \mathrm{h}\right)$ so that the human body does not suddenly feel hot or cold. This suggests the need to conduct more detailed studies on the behavior of the phenomenon in Temuco. Analyzing from the materiality of constructions, direction, etc., several factors may explain more precisely the behavior of the UHI phenomenon in Temuco.

In the temperature profiles in Figure 5, there is a high correlation between the temperature recorded at the Maquehue station and the temperature change in the city. Thus, using linear regressions, per hour 
equations were determined to describe the temperature profile of the zones with the highest temperature in the city (Z1, Z2, Z3 and Z4) based on the temperature at Maquehue. Temperature profiles were modeled for a third heat wave that occurred in March 2020 and using an example, the real temperature and the modeled one in zone 3 (Z-3) were compared from the temperature at the Maquehue station (Figure 6).

Figure 6 shows that the values obtained from the modeling are very close to the real temperature profiles that occurred during that same heat wave event. Here, it was determined that the average real and modeled temperature differences in the 72 -hour period reached $1^{\circ} \mathrm{C}$ and the correlation coefficient was 0.98. This strong correlation suggests it is possible to determine the temperature in the different zones of the city from the temperature of the weather station located outside the city (Maquehue). This would also imply that it is possible to know the past profiles and the prediction for the future of heat wave events based on climate change scenarios. Nevertheless, additional studies are needed to verify these hypotheses and in that sense they represent a continuation of the work presented here.

It has been studied that the UHI phenomenon has direct influence on the power consumption of buildings in cities ${ }^{35-38}$. Hinkel (2003) and Silva (2014) determined UHI occur not only in high-temperature seasons, but it is also possible to detect them in low-temperature seasons ${ }^{39,22}$. Stewart and Oke (2012) determined that in low-temperature seasons UHI can cause a drop in power consumption for heating ${ }^{40}$. Therefore, it is estimated that the occurrence of $\mathrm{UHI}$ in winter in Temuco contributes to the reduced power requirement for heating. However, Capelli (2005) maintain that in high-temperature seasons, there is an increase in energy demand for air conditioning ${ }^{41}$, which is why an equalization in total energy demand is also expected.

\section{Conclusions}

In this work the combined use of methodologies to capture temperature records was compared and contrasted and in addition the urban heat islands (UHI) of Temuco, Chile were simulated and located.

The contrasted methodologies (mobile transects and fixed stations) are used to analyze atmospheric urban heat islands (UHI'a). To capture temperature records with the mobile transect methodology three cars were used that crossed certain sectors of the city between 20:00 and 20:30 h. Each circuit was contrasted with isothermal maps generated with the capture of temperature records from 23 fixed stations belonging to the National Monitoring Network (ReNaM). The three routes showed a moderate correlation, obtaining coefficients of 0.55 (transect 1), 0.61 (transect 2) and 0.62 (Transect 3 ), which means that all the data have a moderate similarity among them. The maximum temperature differences between the values obtained with both methodologies in each circuit was $1.76^{\circ} \mathrm{C}$ (transect 1 ), $2.91^{\circ} \mathrm{C}$ (transect 2) and $2.7^{\circ} \mathrm{C}$ (transect 3), whereas the average temperature differences were $0.72^{\circ} \mathrm{C}$ (transect 1), $1.6^{\circ} \mathrm{C}$ (transect 2) and $1.2^{\circ} \mathrm{C}$ (transect 3). With respect to the standard deviation, results of 0.5 (transect 1), 0.65 (transect 2) and 0.91 (transect 3) were obtained, all values close to the accuracy of the sensor that do not alter the classification of the UHI intensity. It may be concluded that the methodologies are 
indeed compatible for the combined use of the data due to the high similarity in the results obtained between them.

UHI were simulated and located using the fixed station methodology, creating color isothermal maps that represent the sectors with the highest temperature inside the city. Additionally, fluctuation plots were made with the sectors that had higher and lower temperature inputs. The temperatures from the city's official weather station (Maquehue station) were compared to visualize the behavior of the sector over the 24 hours of the day.

The maximum temperature reached in Temuco was $33.1^{\circ} \mathrm{C}$ at $14: 00$, whereas the Maquehue station recorded $25.4^{\circ} \mathrm{C}$ at the same time. Therefore, the UHI were simulated at that time. The temperature differences reached inside the city varied between $0.5^{\circ} \mathrm{C}$ and $3.4^{\circ} \mathrm{C}$, with intensities being classified as weak and moderate. However, the difference is categorical when the points of the city were compared with a sector outside it (Maquehue Station): the intensities varied from $10.1^{\circ} \mathrm{C}$ until $13^{\circ} \mathrm{C}$. These high temperature differences classify the phenomenon as extremely strong UHI, which represents a high risk to human health.

The contributions of this study are the comparison of the methodologies used to capture temperature data in the analyses of UHI'a, as well as the demonstration of the reliability and complementarity of the two methodologies. Additionally, it provides an information framework on the location and behavior of urban heat islands using contrasted methodologies, which provides a theoretical foundation for a better understanding of the phenomenon.

\section{Declarations}

\section{Author contributions}

A. M-S. made the following contribution: Methodology, Validation, Formal analysis, Research, Supervision. M. V. made the following contribution: Conceptualization, Research, Writing - Original Draft P. V. made the following contribution: Review \& Editing A. M-R. made the following contribution: Conceptualization, Simulation of Urban heat Islands

\section{Competing interests}

The authors declare no competing interests.

\section{References}

1. Steffens, A., Piccolo, M., Gonzalez, H., Navarrete, G. \& Lara, M. La Isla de Calor en Temuco, Chile: Situacion invernal. Rev. Geofis. 46, 5-16. https://revistas.um.es/geografia/article/view/47211 (1997). 
2. Fuentes, A. Islas de calor urbano en Tampico, México. Impacto del microclima a la calidad del hábitat. Rev. Nova Scientia. 7, 495-515 (2014)

3. Sarricolea, P., Aliste, E., Castro, P. \& Escobedo, C. Análisis de la máxima intensidad de la isla de calor urbana nocturna de la ciudad de Rancagua (Chile) y sus factores explicativos. Rev. Climatológica. 8, 71-84 (2008)

4. Oke, T.R. City size and urban heat island. Atmospheric Environment. 7, 769-779. https://doi.org/10.1016/0004-6981(73)90140-6 (1973)

5. Stevović, S., Mirjanić, D. \& Durić, S. Theory and smart practice in the reduction of negative effects of urban heat island. Thermal Science. 22, 1011-1031. https://doi.org/10.2298/TSCl170530128S (2018)

6. García, O., Jáuregui, E., Toudert, D. \& Tejeda, A. Detection of the urban heat island in Mexicali, B. C., México and its relationship with land use. Atmosfera. 20, 111-131 (2007)

7. Contreras, A., Salas, J., Velasquez, G. \& Quevedo, H. Determinación de la isla de calor urbano en ciudad Juarez mediante programa de cómputo CULCYT. Clima urbano. 5, 3-16 (2008)

8. Jones, P., Lister, D. \& Li, Q. Urbanization effects in large-scale temperature records, with an emphasis on China. Journal of Geophysical Research: Atmospheres. 113, 1-12. https://doi.org/10.1029/2008JD009916 (2008)

9. Pachauri, R. \& Meyer, L. Informe de síntesis. Contribución de los Grupos de trabajo I, II y III al Quinto Informe de Evaluación del Grupo Intergubernamental de Expertos sobre el Cambio Climático. Ginebra: IPCC (2014)

10. Pachauri, R. \& Reisinger, A. Informe de síntesis. Contribución de los Grupos de trabajo I, II y III al Cuarto Informe de evaluación del Grupo Intergubernamental de Expertos sobre el Cambio Climático Ginebra: IPCC (2007)

11. Feo, O. et al. Climate change and health in the andean region. Rev. Peru. Med. Exp. Salud Publica. 26, 83-93 (2009)

12. Ángel, L., Ramírez, A. \& Domínguez, E. Isla de Calor y cambios espacio-temporales en la Ciudad de Bogotá. Rev. Acad. Colombia. 34, 173-183 (2010)

13. Alomar, G. \& Llop, J. La isla de calor urbana de Palma (Mallorca, Islas Baleares): avance para el estudio del clima urbano en una ciudad litoral mediterránea. Boletín la Asoc. Geógrafos Españoles. 78, 392-418. https://doi.org/10.21138/bage.2404 (2018)

14. Cunningham, B. Overwhelmed: Heat waves are on the rise, putting city dwellers in danger. Science News. 1, 18-21. (2018)

15. Kuznetsova, I., Brusova, N. \& Nakhaev, M. Moscow Urban Heat Island: Detection, boundaries, and variability. Russian Meteorology and Hydrology. 42, 305-313. https://doi.org/10.3103/S1068373917050053 (2017)

16. Ichim, P., Sfîcă, L. \& Kadhim, A. Characteristics of Nocturnal Urban Heat Island of laşi during a Summer Heat Wave. Advancing earth and space science. 11, 253-260. https://doi.org/10.1016/S1352-2310(97)00136-2 (2018) 
17. Jaureguı, E. Heat Island Development In Mexıco City. Atmospheric Environment. 31 (22), 3821-3831. https://doi.org/10.1016/S1352-2310 (1997)

18. Balogun, A. Observed urban heat island characteristics in Akure, Nigeria. Environmental science and technology. 6 (1), 1-8. https://doi.org/10.5897/AJEST11.084 (2012)

19. Schmidlin, T. The Urban Heat Island at Toledo, Ohio. Journal of Science. 89 (3), 38-41. http://hdl.handle.net/1811/23313 (1989)

20. Hawkins, T., Brazel, A., Stefanov, W., Bigler, W. \& Saffell, E. The role of rural variability in urban heat island determination for Phoenix, Arizona. Journal of Applied Meteorology. 43 (3), 476-486. https://doi.org/10.1175/1520-0450(2004)043<0476:TRORVI>2.0.CO;2 (2004)

21. Hedquist, B. \& Brazel, A. Urban, residential, and rural climate comparisons from mobile transects and fixed stations: Phoenix, Arizona. Journal of the Arizona-Nevada Academy of Science. 38, 77-87. https://doi.org/10.2181/1533-085(2006)38[77:URARCC]2.0.C0;2 (2006)

22. Silva, V., Almeida, L., Silva, C., Carvalho, H. \& Camargo, R. Mobile transect for identification of intraurban heat islands in Uberlandia, Brazil. Revista Ambiente. 9, 445-458. http://dx.doi.org/10.4136/ambi-agua.2187 (2014)

23. Martínez, J. Estudio de la isla de calor de la ciudad de Alicante. Investigaciones Geográficas. 62, 8399. https://doi.org/10.14198/INGEO2014.62.06 (2014)

24. Giannopoulou, K., Livada, I., Santamouris, M., Saliari, M., Assimakopoulos, M. \& Caouris, Y. G. On the characteristics of the summer urban heat island in Athens, Greece. Sustainable Cities and Society. 1 (1), 16-28. https://doi.org/10.1016/j.scs.2010.08.003 (2011)

25. Shumilov, O., Kasatkina, E. \& Kanatjev, A. Urban heat island investigations in Arctic cities of northwestern Russia. Journal of Meteorological Research. 31, 1161-1166. https://doi.org/10.1007/s13351-017-7048-8 (2017)

26. Erell, E. \& Williamson, T. Intra-urban differences in canopy layer air temperature at a mid-latitude city. International Journal of Climatology. 27, 1243-1255. https://doi.org/10.1002/joc.1469 (2007)

27. Stewart, I. A systematic review and scientific critique of methodology in modern urban heat island literature. International Journal of Climatology. 31, 200-217. https://doi.org/10.1002/joc.2141 (2011)

28. Konstantinov, P., Grishchenko, P. \& Varentsov, M. Mapping urban heat islands of Arctic cities using combined data on field measurements and satellite images based on the example of the city of Apatity (Murmansk Oblast). Izvestiya, Atmospheric and Oceanic Physics. 51, 992-998. https://doi.org/10.1134/S000143381509011X (2015)

29. Hardy, C. \& Nel, A. Data and techniques for studying the urban heat island effect in Johannesburg. Remote Sensing and Spatial information Sciences. 40, 203-206. https://doi.org/10.5194/isprsarchives-XL-7-W3-203-2015 (2015)

30. Espinoza, P. \& Aravena, H. Análisis de los factores condicionantes sobre las temperaturas de emisión superficial en el área metropolitana de Valparaíso. Santiago: Universidad de Chile (2010) 
31. Moreno, C. El estudio de la isla de calor urbana en el ámbito mediterráneo: una revisión bibliográfica. Rev. Bibliografica de geografia y ciencias sociales. 21, 1-32. (2016)

32. Kundu, S. \& Kumar, N. Reducing Urban Heat Islands: Compendium of strategies, India Int. Conf. Power Electron. IICPE. 1, 1-24 (2017)

33. Espinoza, S. El estudio de la Isla de Calor Urbana de Superficie del Área Metropolitana de Santiago de Chile con imágenes Terra-MODIS y Análisis de Componentes Principales. Revista de geografía Norte Grande. 141, 123-141. http://dx.doi.org/10.4067/S0718-34022014000100009 (2014)

34. Hajat, S., Kovats, R., Atkinson, R. \& Maines, A. Impact of hot temperatures on death in London: a timeseries approach. J Epidemiol Community Health. 72, 56-367.

https://doi.org/10.1136/jech.56.5.321 (2002)

35. Tran, H., Uchihama, D., Ochi, S. \& Yasuoka, Y. Assessment with satellite data of the urban heat island effects in Asian mega cities. Int. J. Appl. Earth Obs. Geoinf. 8, 34-48.

https://doi.org/10.1016/j.jag.2005.05.003 (2006)

36. Lee, S. \& Baik, J. Statistical and dynamical characteristics of the urban heat island intensity in Seoul. Theoretical and Applied Climatology. 100, 227-237. https://doi.org/10.1007/s00704-009-0247-1 (2010)

37. Sidiqui, P., Huete, A. \& Devadas, R. Spatio-temporal mapping and monitoring of Urban Heat Island patterns over Sydney, Australia using MODIS and Landsat-8. Earth Obs. Remote Sens. Applied. 4, 217-221. https://doi.org/10.1109/EORSA.2016.7552800 (2016)

38. Deilami, K. Modelling the urban heat island intensities of alternative urban growth management policies in Brisbane. Brisbane: Queensland University of Technology.

https://doi.org/10.5204/thesis.eprints.107656 (2017)

39. Hinkel, K. Nelson, F., Klene, A. \& Bell, J. The urban heat island in winter at barrow, Alaska. Int. J. Climatol .23, 1889-1905. https://doi.org/10.1002/joc.971 (2003)

40. Stewart, I, Oke T. Local Climate Zones for urban temperatures studies. Bulletin of the American Meteorological Society. 93, 1879-1900. https://doi.org/10.1175/BAMS-D-11-00019.1 (2012)

41. Capelli, A., Piccolo, M. \& Campo, A. Clima urbano de Bahía Blanca. Revista universitaria de geografía. $15,183-186$ (2006)

42. Organización de las Naciones Unidas (ONU) Boletín Demográfico - Chile. Temuco (2019)

43. Instituto Nacional de Estadísticas (INE). Chile, Resultados Censo 2002 de Población. Temuco (2002)

44. Instituto Nacional de Estadísticas (INE). Resultados Censo 2017 de Población. Temuco (2017)

45. Fuentes, C. Climatología urbana por modificación antropogénica. Alteración del balance de energía natural. Rev. de la Facultad de Arquitectura Universidad Autónoma de Nueva León. 9, 73-91 (2015)

46. Biblioteca Nacional del Congreso. Clima y vegetación Región de la Araucanía, https://www.bcn.cl/siit/nuestropais/relieve.html (2017) [accessed 07 November 2019].

47. Godoy, G. Modelo de la Isla de Calor Atmosférico y Superficial: Factores en Común y alternativas para la Mitigación de su Efecto en salud humana y medioambiente urbano Factores claves y 
limitantes. Dinámica de Sistemas. 1, 1-21. https://doi.org/10.13140/2.1.1761.6646 (2017)

48. Zühlke, J. Die Verbreitung von Wissen zu Controlling-Instrumenten. Wiesbaden: Deutscher Universitäts-Verlag (2007)

49. Pardo, J. Estudio de la isla de calor de la ciudad de Ibiza. Investig. Geográficas. 44, 55-73. https://doi.org/10.14198/INGE02007.44.03 (2014)

50. Amatriain, X., Jaimes, A., Oliver, N. \& Pujol, J.M. Data mining methods for recommender systems. Springer, Boston, MA. https://doi.org/10.1007/978-0-387-85820-3_2(2011)

51. Van Kreveld, M. Algorithms for triangulated terrains. In international Conference on Current Trends in Theory and Practice of Computer Science. Springer, Berlin, Heidelberg. https://doi.org/10.1007/3540-63774-5_95 (1997)

52. Fernández, F. Manual de Climatología Aplicada. Clima, Medioambiente y Planificación. (1996)

\section{Figures}

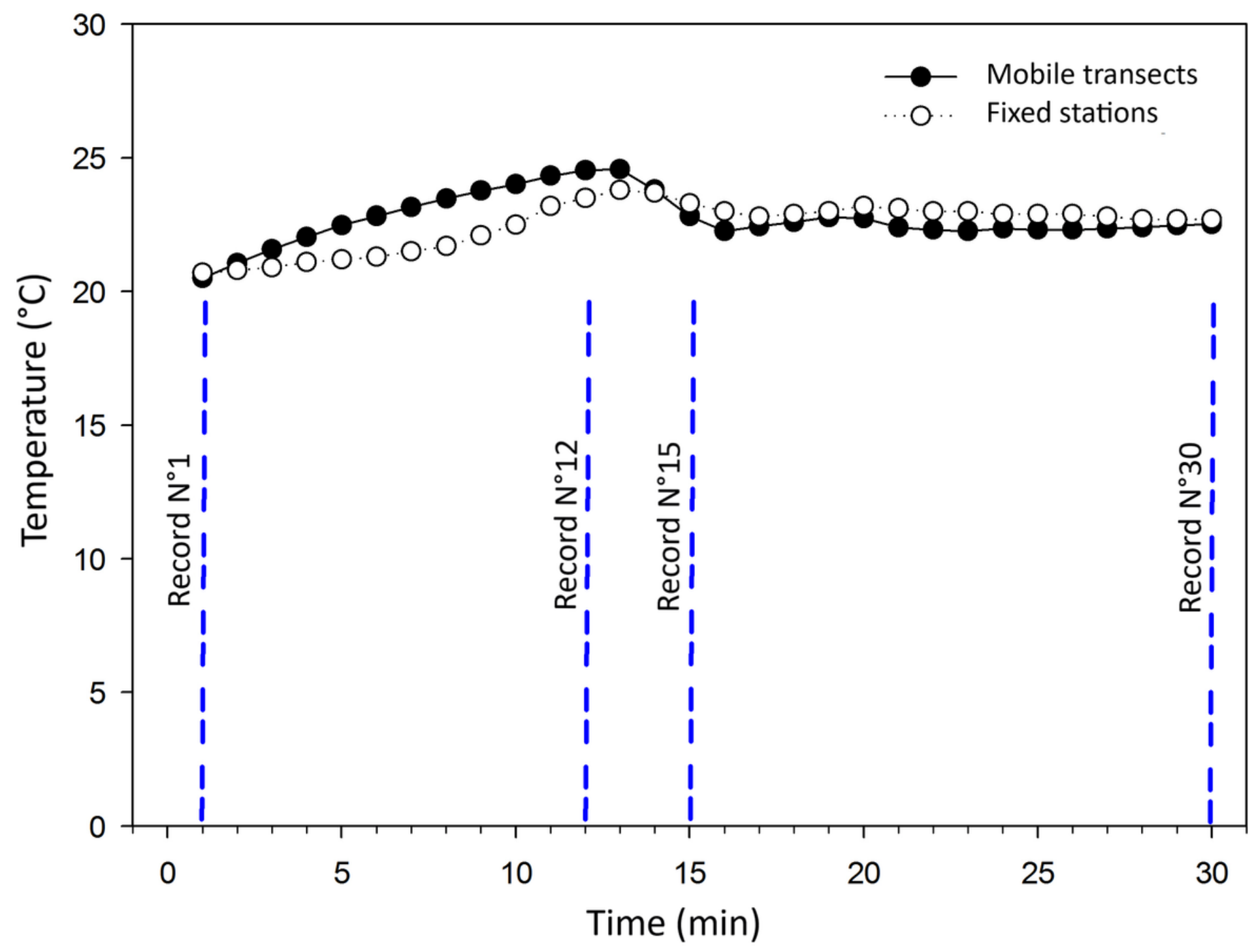

Figure 1 
Comparison of temperatures recorded in Transect 1 and UHI simulations based on fixed stations for the time period corresponding to $20: 00 \mathrm{~h}$ and 21:00 $\mathrm{h}$.
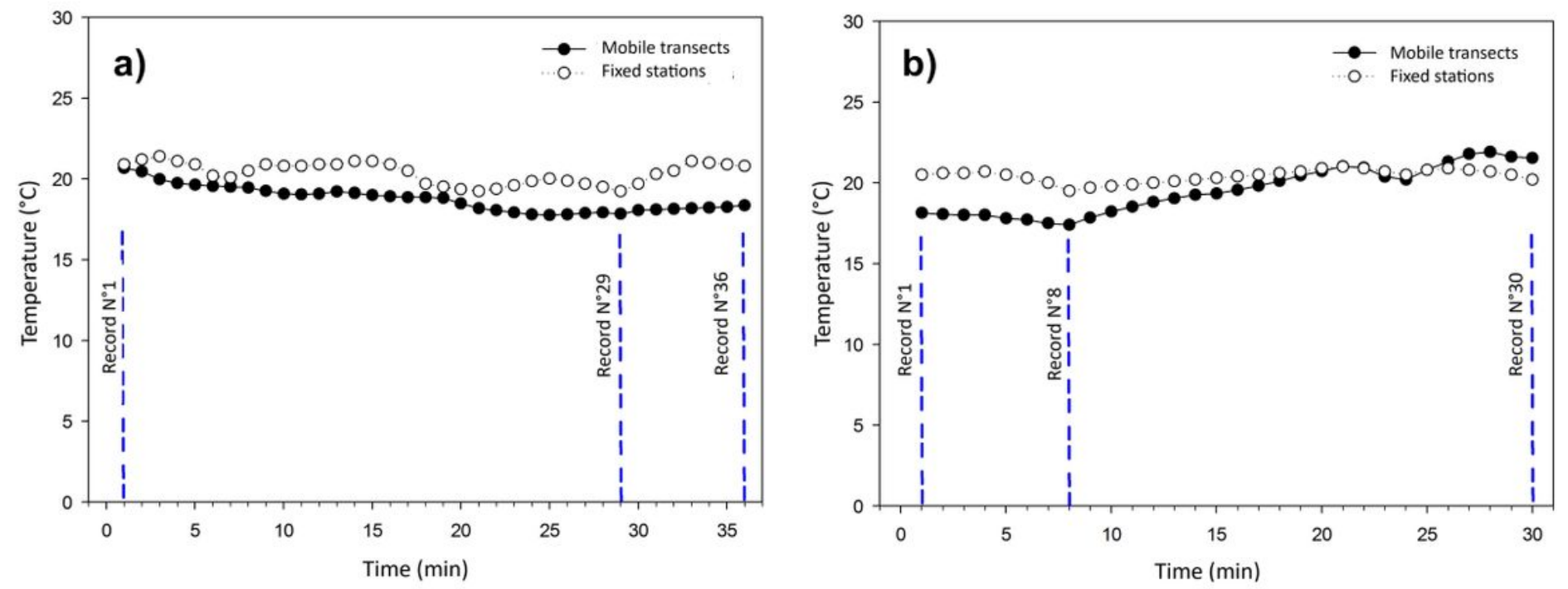

Figure 2

a) Comparison of temperatures recorded in Transect 2 and UHI simulations based on fixed stations for the time period corresponding to 20:00 h and 21:00 h. b) Comparison of temperatures recorded in Transect 3 and $\mathrm{UHI}$ simulations based on fixed stations for the time period corresponding to $20: 00 \mathrm{~h}$ and $21: 00 \mathrm{~h}$.

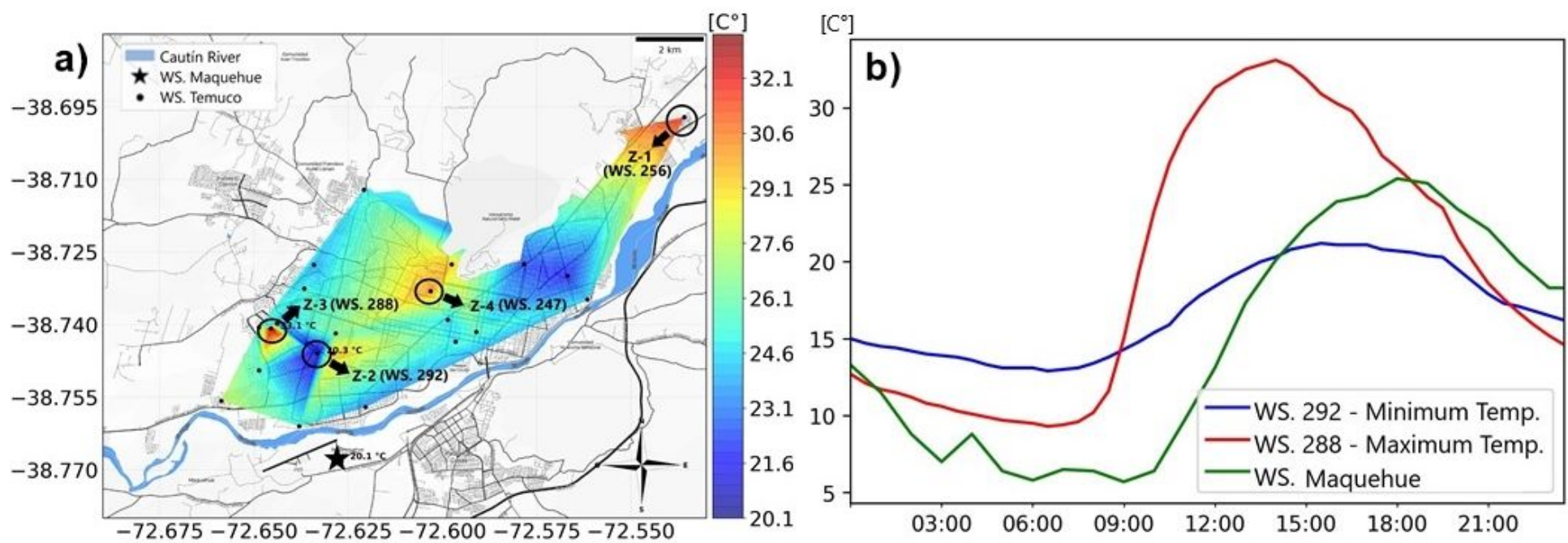

Figure 3

Simulation of the UHI phenomenon in Temuco using fixed station methodology (a) and fluctuation plot (b) on December 4, 2019 between sectors that have the maximum and minimum temperature at 14:00 $\mathrm{h}$. Note: The designations employed and the presentation of the material on this map do not imply the expression of any opinion whatsoever on the part of Research Square concerning the legal status of any 
country, territory, city or area or of its authorities, or concerning the delimitation of its frontiers or boundaries. This map has been provided by the authors.
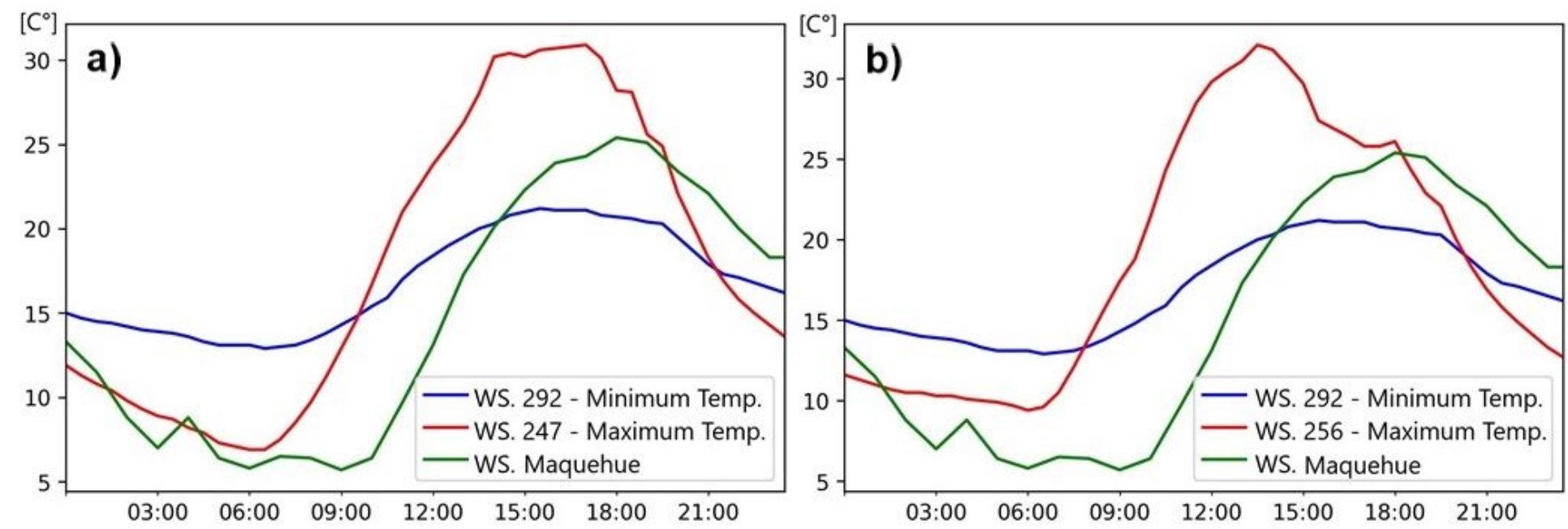

Figure 4

Fluctuation plot with stations in the city that record high temperatures compared to their adjacent sectors. Station 247 left plot (a). Zone $4-38.733095,-72.6031539$. Station 256 right plot (b). Zone 1 $-38.697133,-72.535842$.

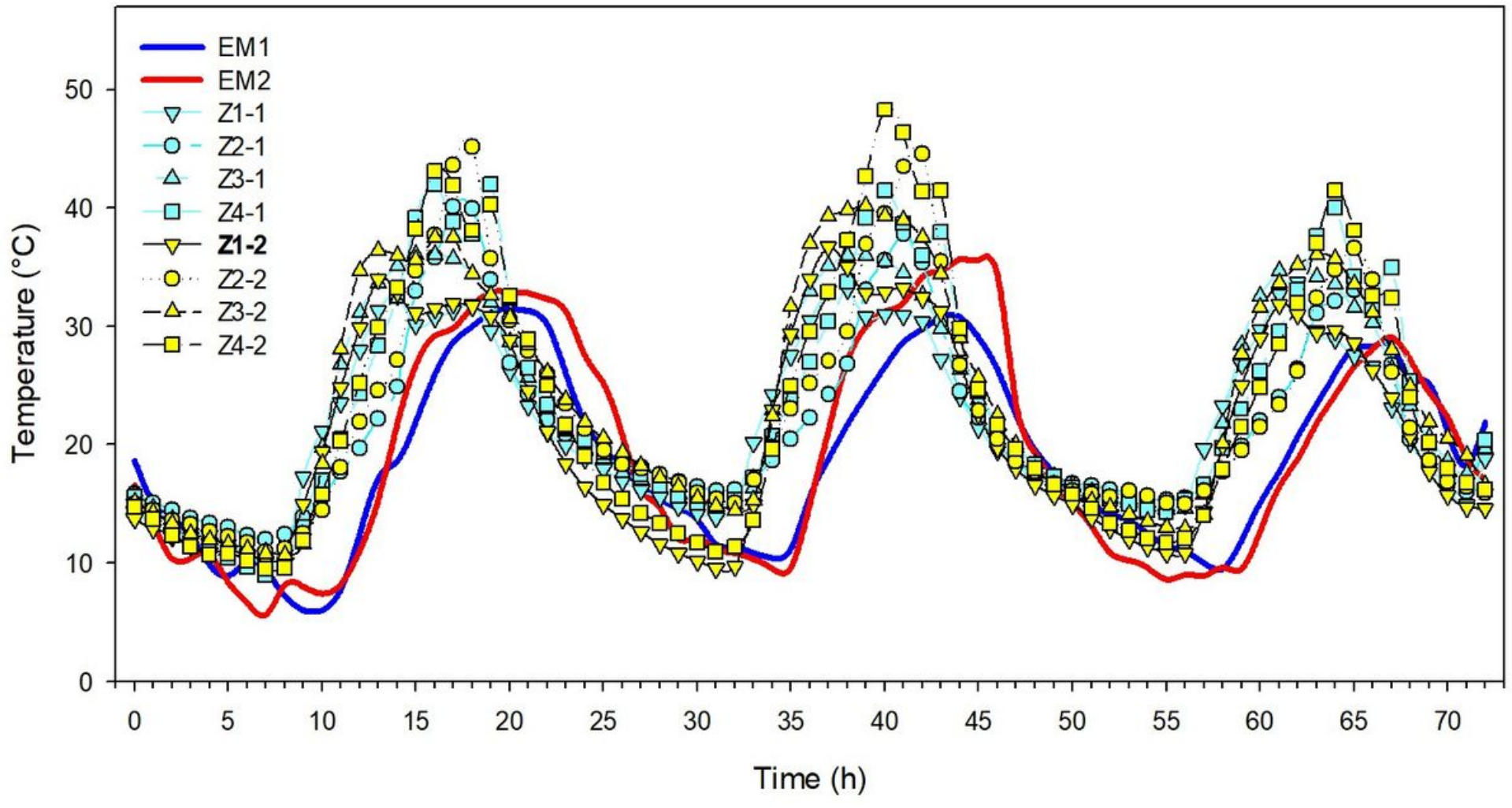

Figure 5 
Comparison of temperature for two heat wave episodes between Maquehue station (MS1 and MS2) and the zones with the highest temperature in Temuco $(Z 1, Z 2, Z 3, Z 4)$.

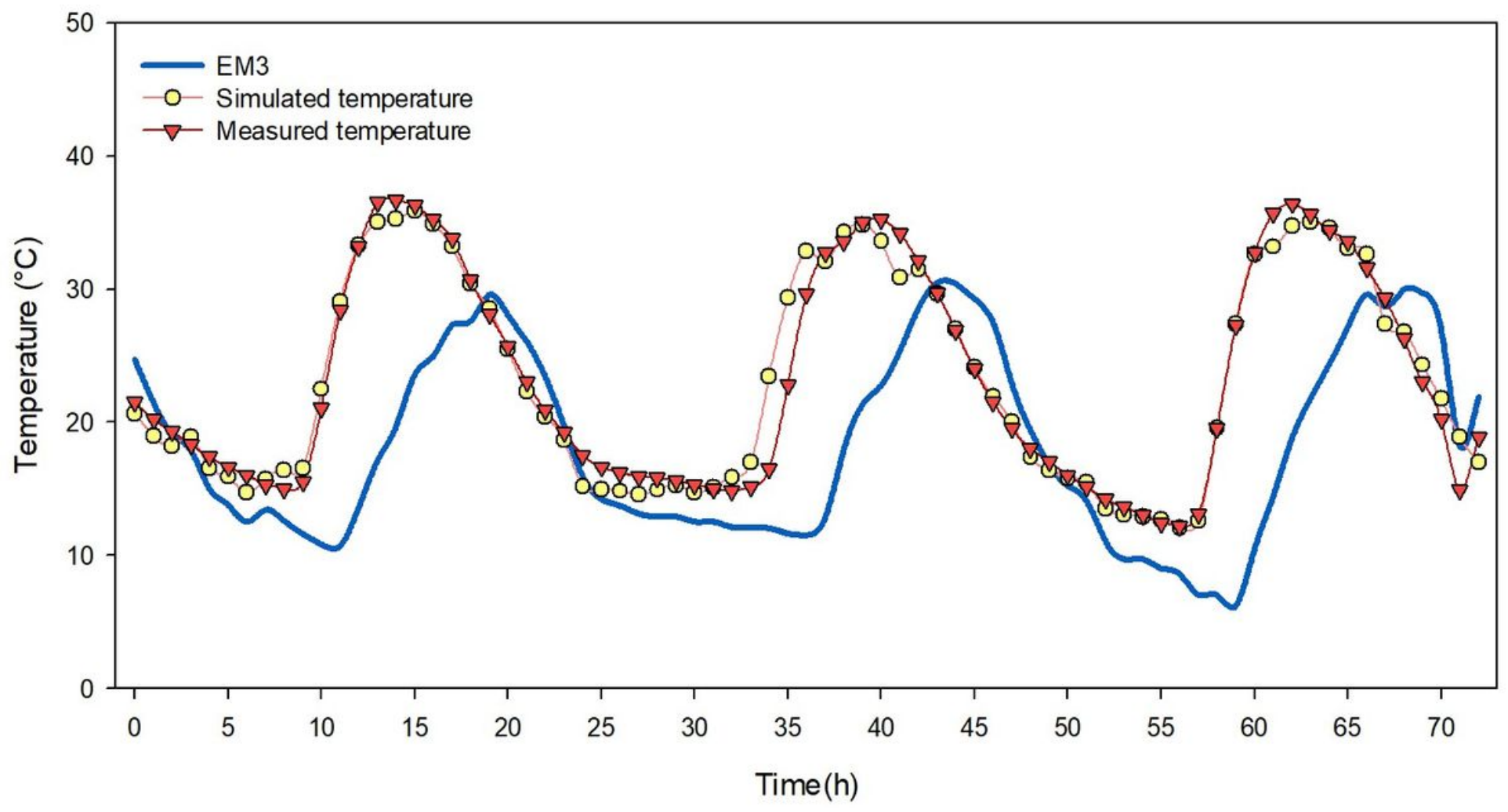

Figure 6

Comparison of real and modeled temperature profiles for zone 3 in Temuco based on the temperatures of the Maquehue station (MS) located outside the city.

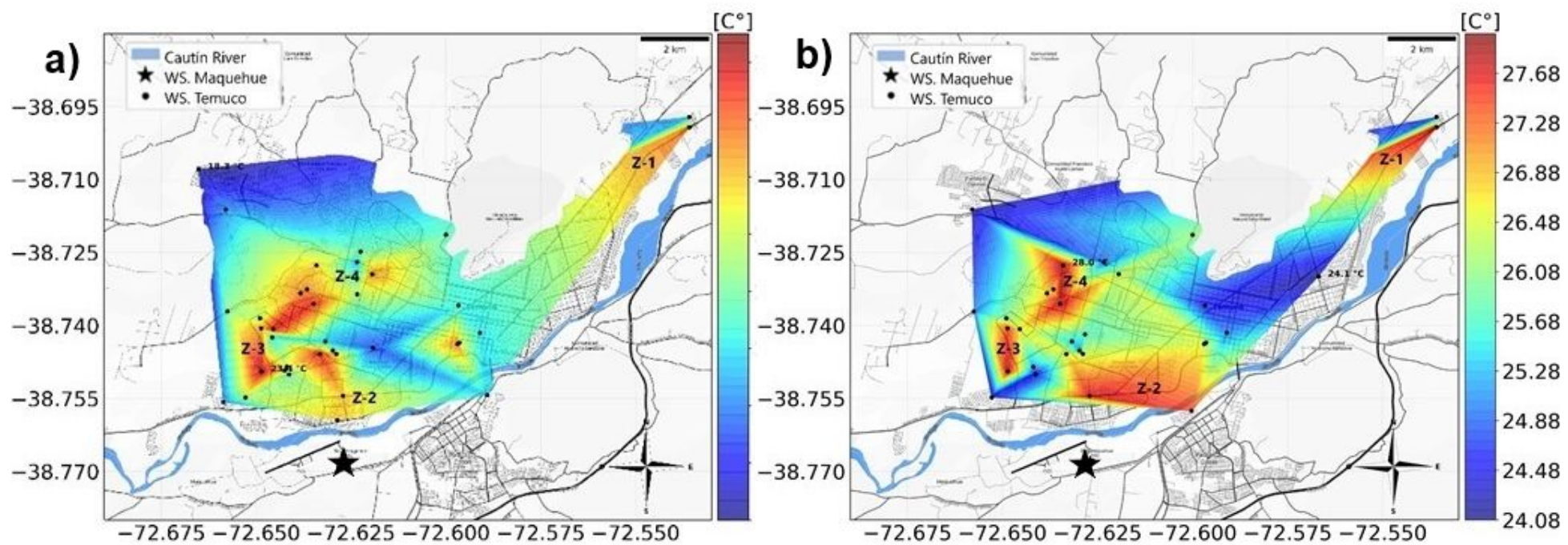

Figure 7

Location of the UHI in Temuco on November 27, 2017 at 9:00 p.m. (left) and 19 January 2018 at 8:00 p.m (right) to determine the circuit to carry out the measurements with mobile transects. Note: The 
designations employed and the presentation of the material on this map do not imply the expression of any opinion whatsoever on the part of Research Square concerning the legal status of any country, territory, city or area or of its authorities, or concerning the delimitation of its frontiers or boundaries. This map has been provided by the authors.

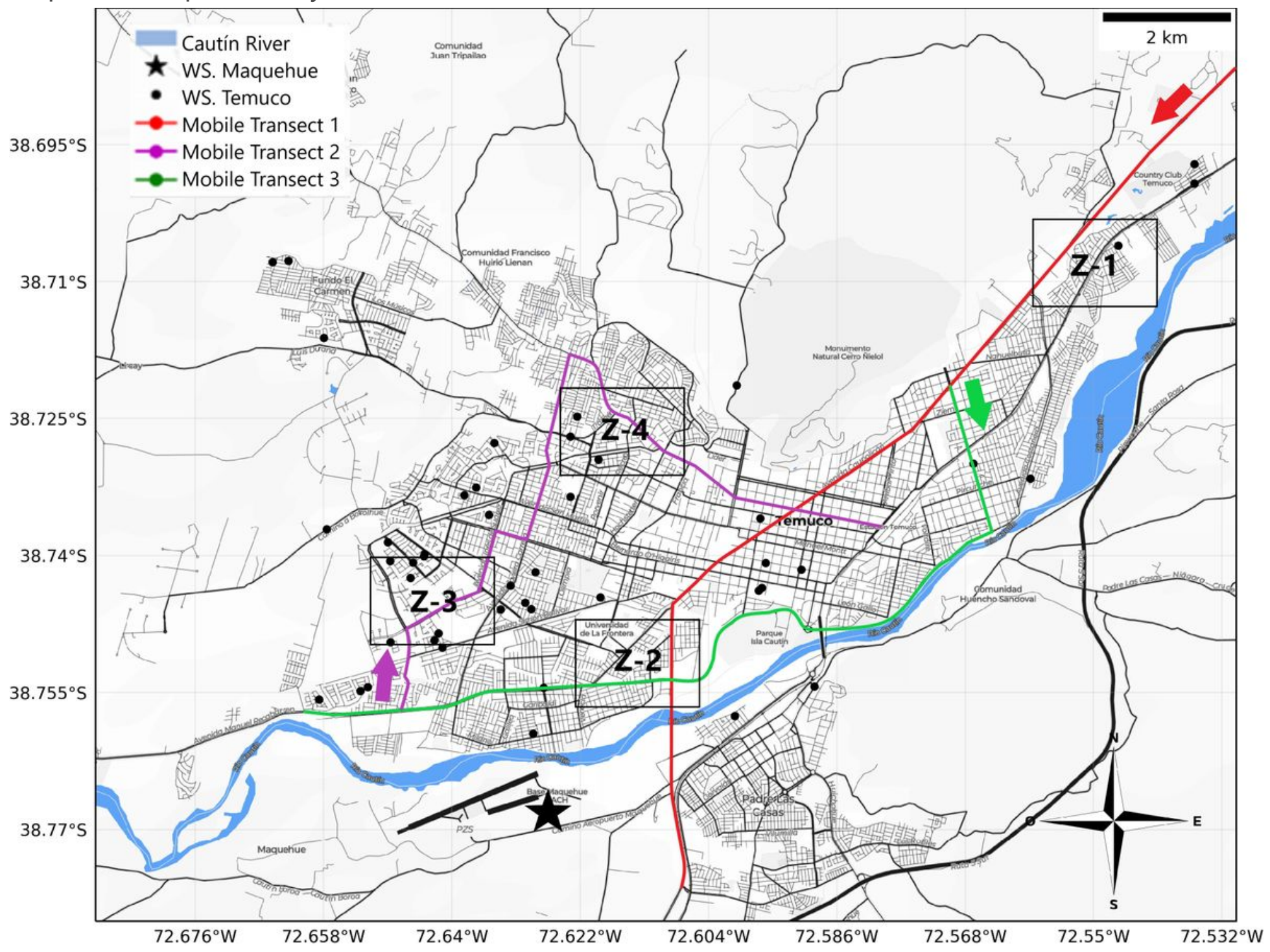

Figure 8

Route to capture data with the mobile transect method (red, magenta and green lines) and fixed stations distributed in different points of the city (black points). Note: The designations employed and the presentation of the material on this map do not imply the expression of any opinion whatsoever on the part of Research Square concerning the legal status of any country, territory, city or area or of its authorities, or concerning the delimitation of its frontiers or boundaries. This map has been provided by the authors. 